Egyptian Journal of Aquatic Biology \& Fisheries

Zoology Department, Faculty of Science,

Ain Shams University, Cairo, Egypt.

ISSN $1110-6131$

Vol. 24(1): 525 - 539 (2020)

www.ejabf.journals.ekb.eg

\title{
Pomegranate peel extract in situ assisted phytosynthesis of Silver Nanoparticles decorated Reduced Graphene Oxide as superior sorbents for Zn(II) and Lead(II)
}

\section{Heba El-Sabban ${ }^{*}$, Mona Eid ${ }^{1}$, Yasser Moustafa ${ }^{1}$ and Mohamed Abdel-Mottaleb ${ }^{2}$}

1 Egyptian Petroleum Research Institute, Analysis and Evaluation Department, Cairo, Egypt.

2 Nano-Photochemistry, Solar chemistry and Computational Chemistry Labs, Department of

Chemistry, Faculty of Science, Ain Shams University, 11566 Cairo, Egypt.

"Corresponding Author: heba_elsabban_epri@outlook.com

\section{ARTICLE INFO}

Article History:

Received: March 26, 2019

Accepted: Dec. 28, 2019

Online: Jan. 2020

Keywords:

Phytosynthesis,

Silver nanoparticles,

Pomegranate extract,

Graphene oxide

nanocomposites.

\section{ABSTRACT}

A facile one step phytosynthesis technique was used to prepare Ag-RGO nanocomposites with different silver loading ratios up to $30 \% \mathrm{Ag}$-RGO by weight using pomegranate peel extract (PPE) as reducing and capping agent. These green synthesized Ag-RGO nanocomposites were characterized using $\mathrm{XRD}$, Raman and TEM techniques. The adsorption capacity of Ag-RGO is evaluated under variable experimental conditions such as; contact time, dosage of adsorbent and initial concentration of heavy metals. The adsorption kinetic data were studied, and the uptake process was well described by Freundlich adsorption isotherm model and Pseudo second order kinetic model.

\section{INTRODUCTION}

Contamination of the environment with heavy metals is a noticeable worldwide phenomenon and it causes serious damage to the environment and to human health. Natural resources of water are contaminated with heavy metals as a result of residual discharges from industries, mining and other anthropogenic activities. Among these pollutants, zinc and lead have attracted attention because they are the most released by industries, toxic and have non-biodegradable properties. Several approaches to eliminate these pollutants from water have been tried, such as ; chemical precipitation, ion exchange, membrane filtration, coagulation and flocculation (Uçar et al., 2015). The above-mentioned technologies are expensive and inefficient in treating large quantities so; attention has been directed towards the technology of adsorption. This technology has offers a simple, non-toxic and eco-friendly method for metal ions (Song et al., 2014) . 
Metal nanoparticles and their nanocomposites, especially silver nanoparticles (AgNPs), attracted attention of scientists worldwide in the recent years due to their unique physical and chemical properties which are attributed to their small sizes and large surface area. Silver nanoparticles have potential applications in heavy metal removal (Wang et al., 2012; Al-Qahtani, 2017). However, these adsorbents are difficult to be used in continuous flow systems due to small particle size and instability. To overcome this problem, silver nanoparticles are combined with other sorbents such as porous concrete pebbles and carbon nanotubes (Suman et al., 2015; Rengga et al., 2017). The high surface area to mass ratios of silver nanoparticles can effectively enhance the adsorption capacities of sorbent materials. In this regard, graphene has been brought into great focus due to its attractive and enhanced functionalities in a wide variety of applications. However, the individual graphene sheets tend to irreversibly aggregate or restack to form graphite through the strong $\pi-\pi$ stacking and van der Waals interactions between the planar basal planes of graphene sheets. The serious aggregation certainly hinders the active catalytic sites and subsequently reduces the catalytic activity of graphene. Several approaches such as chemical reduction using chemical reducing agents are either expensive or produces toxic and hazardous by-products. Hence, great efforts are exerted to find environmentally ecofriendly green reducing agents such plant extract, bacteria, fungi, enzymes and algae (Minhas et al., 2018). Plants extracts are available, cheap and eco-friendly because no contaminants can retain and the capability of treating large amount of wastewater within a short time can be achieved (Ahmad et al., 2012) . Pomegranate peel extract (PPE) is employed as a reducing agent for reducing GO sheets in an aqueous (Edison and Sethuraman, 2013). The synthesis technique of (Ag-RGO) nano-composite includes oxidation of graphite via modified Hummers method followed by the reduction of GO-Ag suspension. However, till now, AgNPs decorated RGO is not exploited so far as a superior adsorbent for toxic heavy metal ions from wastewater. The novelty of this study is to remove $\mathrm{Pb}^{2+}$ and $\mathrm{Zn}^{2+}$ heavy metals ions using Ag-RGO nanocomposite which prepared using pomegranate extract as ecofriendly benign reducing agent. The uptake of $\mathrm{Pb}^{2+}$ and $\mathrm{Zn}^{2+}$ metal ions from aqueous solutions wasoptimized at different parameters including time, adsorbent dose and metal ion concentration. Also, the adsorption isotherm and kinetics were studied.

\section{MATERIALS AND METHODS}

\subsection{Materials}

Graphite, potassium permanganate $\left(\mathrm{KMnO}_{4}\right)$, sodium nitrate $\left(\mathrm{NaNO}_{3}\right)$, hydrogen peroxide $\left(\mathrm{H}_{2} \mathrm{O}_{2}, 30 \%\right)$, concentrated sulfuric acid, sodium hydroxide $(\mathrm{NaOH})$ and silver nitrate $\left(\mathrm{Ag} \mathrm{NO}_{3}\right)$ were purchased from Sigma-Aldrich Company. All chemicals are of analytical grade 


\subsection{Preparation of Pomegrante peel extract (PPE)}

$50 \mathrm{~g}$ of Pomegrante peel was boiled for $15 \mathrm{~min}$ in $500 \mathrm{~mL}$ deionized water (Sedki et al., 2015).

\subsection{Phytophabrication of Ag-RGO nanocomposite}

\subsubsection{Preparation of Graphene Oxide (GO) nanosheets}

Graphene oxide was synthesized by modified Hummer method. $5 \mathrm{~g}$ graphite, $2.5 \mathrm{~g}$ sodium nitrate and $115 \mathrm{ml}$ concentrated sulfuric acid were added into a $2 \mathrm{~L}$ beaker under stirring for $10 \mathrm{~min}$. Then, $15 \mathrm{~g}$ potassium permanganate was gradually added into the solution. The mixture was kept under stirring at room temperature for $24 \mathrm{hrs}$. After that, $230 \mathrm{ml}$ distilled water was added to the mixture and as result of the hydration heat, the temperature expanded to $98{ }^{\circ} \mathrm{C}$. The mixture was kept at this temperature for $30 \mathrm{~min}$ under stirring. Finally, $700 \mathrm{~mL}$ distilled water and $300 \mathrm{~mL}$ hydrogen peroxide (30\%) were added to the previous mixture. The obtained product washed 3 times with distilled water. After that, GO was obtained by filtration from the solution and dried in oven at 60 ${ }^{\circ} \mathrm{C}$ for $12 \mathrm{hrs}$ (El-Maghrabi et al., 2017).

\subsubsection{Synthesis of Ag-RGO nanocomposites using PPE}

$30 \mathrm{~mL}$ of PPE was added to $170 \mathrm{~mL}$ of $\mathrm{AgNO}_{3}$ solution $(1 \mathrm{mM})$ at $60{ }^{\circ} \mathrm{C}$ while stirring magnetically for $15 \mathrm{~min}$. For the synthesis of Ag-RGO nanocomposite, three different weights of RGO were added to silver nitrate solution with continuous sonication at $60{ }^{\circ} \mathrm{C}$ for 15 min to provide a weight ratio of AgNPs over RGO in the range from $10 \%$ to $30 \%$. The resultant Ag-RGO nanocomposite were centrifuged and dried (Sedki et al., 2015). The obtained products were designated as $10 \mathrm{wt} \% \mathrm{Ag}$-RGO, $20 \mathrm{wt} \% \mathrm{Ag}-\mathrm{RGO}$ and 30 wt\% Ag-RGO.The reductive ability of PPE may be attributed to the reducing biomolecules present in the peel of pomegranate such as ellagic tannins, ellagic acid and gallic acid (Edison and Sethuraman, 2013).

\subsection{Instrumentation}

The phase structures of the prepared products were characterized by X-ray diffraction analysis (XRD) using X'Pert pro Pan-analytical instrument. Dispersive Raman spectrometer (BRUKER-SENTERRA, Germany) equipped with an integral microscope (Olympus) was applied on GO, RGO and Ag-RGO samples to detect the D and G characteristic bands. Atomic Absorption Spectrophotometer (AAS), Hitachi model No. $\mathrm{Z}-7000$ was used for measuring the residual concentrations of $\mathrm{Zn}(\mathrm{II})$ and $\mathrm{Pb}(\mathrm{II})$ metals.

\subsection{Sorption Studies}

Batch adsorption experiments were carried out at room temperature by shaking a series of bottles containing the desired dose of adsorbent in a predetermined concentration of heavy metal solution. In order to evaluate the optimum loading ratio of $\mathrm{Ag}$ in $\mathrm{Ag}-\mathrm{RGO}$ 
nanocomposites for effective removal of metals, typically, $2.5 \mathrm{~g} / \mathrm{L}$ of $10 \mathrm{wt} \%, 20 \mathrm{wt} \%$ and $30 \mathrm{wt} \%$ Ag-RGO were individually added to a series of $20 \mathrm{~mL}$ of $\mathrm{Zn}^{2+}$ and $\mathrm{Pb}^{2+}$ aqueous solutions $\left(50 \mathrm{mg} \mathrm{L}^{-1}\right.$ ) The suspension was allowed to remain magnetically stirred at a continuous agitation of $300 \mathrm{rpm}$ for $4 \mathrm{hrs}$. The concentrations of the remaining lead (II) and zinc (II) ions in the aqueous phase were determined using atomic absorption spectrophotometer to determine the optimum loading ratio of silver in Ag-RGO nanocomposite. The amount of metal ions adsorbed at equilibrium, $\mathrm{q}_{\mathrm{e}}\left(\mathrm{mg} \mathrm{g}^{-1}\right)$, was calculated using the following equation (Uçar et al., 2015): $q_{e}=\frac{\left(C_{o}-C_{e}\right) \mathrm{V}}{\mathrm{W}}$. The amount of metal ion adsorbed $\mathrm{q}_{\mathrm{t}}\left(\mathrm{mg} \mathrm{g}^{-1}\right)$ at time $(\mathrm{t})$, was computed by the following equation: $q_{t}=\frac{\left(C_{o}-C_{t}\right) \mathrm{v}}{\mathrm{w}}$. Where, $C_{o}$ and $C_{\mathrm{t}}$ are the initial and final concentrations of the heavy metals $(\mathrm{mg} / \mathrm{L})$ present in solution before and after adsorption after period of time $\mathrm{t}$ respectively. The volume of solution used is represented by $\mathrm{V}(\mathrm{L})$, while $\mathrm{W}$ represent the mass $(\mathrm{g})$ of the adsorbent used. While adsorption efficiency was obtained as follows (Bernard et al., 2013): $\mathrm{R}(\%)=\frac{\left(C_{o}-C_{t}\right) * 100}{C_{o}}$

\subsubsection{Effect of contact time}

In order to evaluate kinetic data, the initial $\mathrm{Zn}, \mathrm{Pb}$ concentrations $(50 \mathrm{ppm})$, solution $\mathrm{pH}$ (6.0) and adsorbent concentration (2.5 g/L) were kept constant and shakenin a shaker incubator then samples were removed and filtered at each pre-determined timeintervals for the analysis of residual metal concentration in solution by Atomic absorptionspectroscopy (AAS).

\subsubsection{Effect of adsorbent concentrations}

The effect of adsorbent concentrations on the adsorption of $\mathrm{Zn}, \mathrm{Pb}$ were studied in the range of $1.5 \mathrm{~g} / \mathrm{L}$ to $5 \mathrm{~g} / \mathrm{L}$. $\mathrm{pH}$ of solution was maintained constant at 6.0 , the initial $\mathrm{Zn}$, $\mathrm{Pb}$ concentrationwas $50 \mathrm{mg} / \mathrm{L}$ and the contact time was $4 \mathrm{hrs}$.

\subsubsection{Effect of the initial metal ions concentration}

The effect of the initial heavy metal concentration was studied at different concentrations ofmetal ions (from 5 to $200 \mathrm{mg} / \mathrm{L}$ ) at $\mathrm{pH}(6.0)$, contact time of $4 \mathrm{hrs}$ and adsorbent concentration $(5 \mathrm{~g} / \mathrm{L})$ were kept constant.

\section{RESULTS AND DISCUSSION}

\subsection{Characterization of adsorbent}

The (XRD) pattern of the prepared GO, RGO, Ag Nps and Ag-RGO nanocomposites with different $\mathrm{Ag}$ loading ratios are shown in Fig. 1. The (001) strongest diffraction peak of graphene oxide appears around $2 \theta=11.4^{\circ}$ [29] while RGO showed a characteristic broad peak centered at an angle of $22^{\circ}$ [30]. Diffraction peaks were observed in Ag-RGO 
nanocomposites at $2 \theta$ values of $38^{\circ}, 44^{\circ}, 77^{\circ}$ and $81^{\circ}$ corresponding to (111), (200), (220) and (311) crystal planes of AgNPs. The broadening of these peaks is mostly due to the effect of nano-sized silver particles.

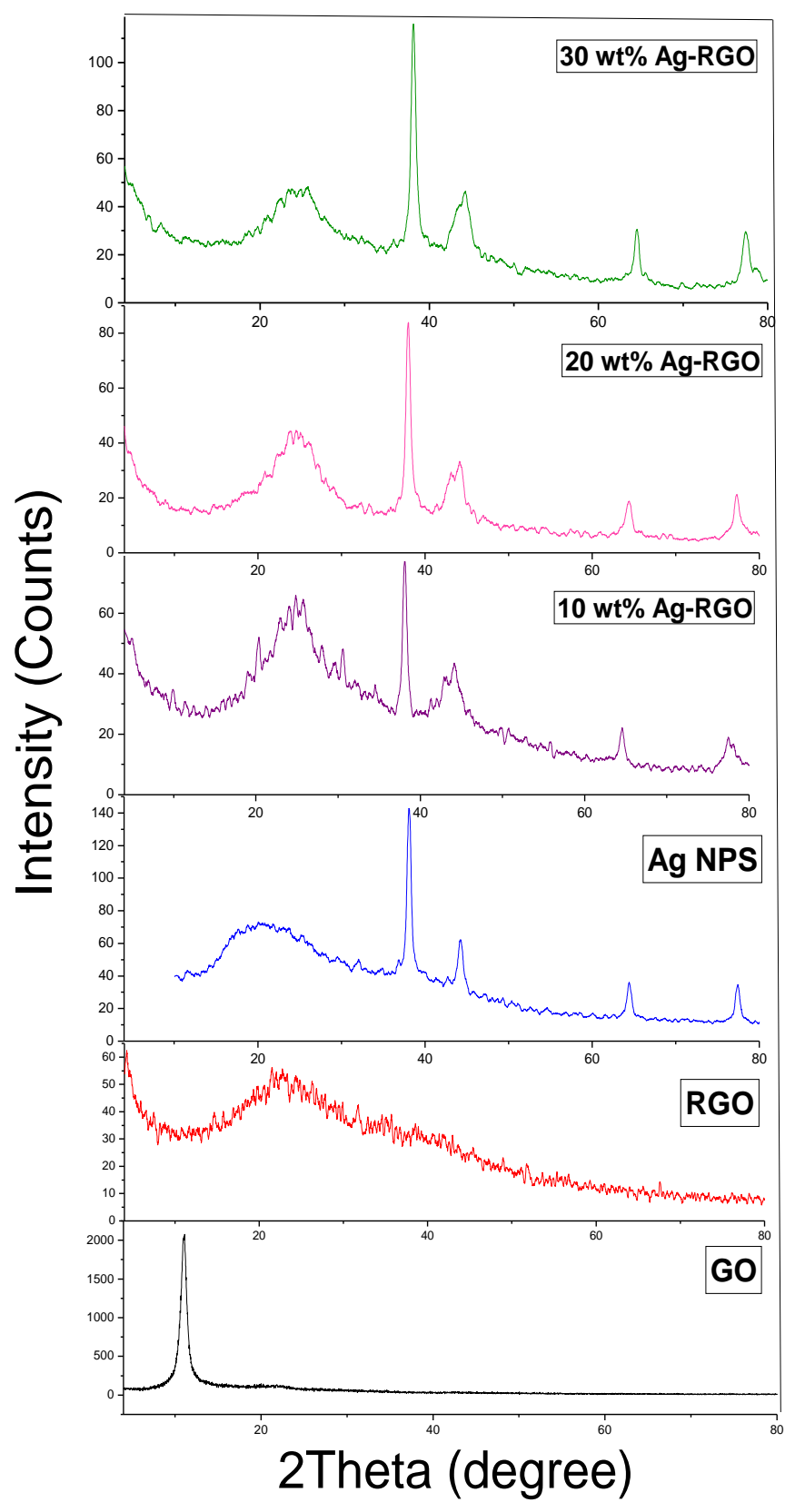

Figure 1: X-ray diffraction (XRD) patterns of graphene oxide $(\mathrm{GO})$, reduced graphene oxide (RGO), Ag NPs and Ag-RGO nanocomposites with different Ag loading wt. ratios. 
The morphology of the surface was monitored using Transmission electron micrography. In Fig. (2a), TEM shows silver to be nanosized and uniformly dispersedand most of the NPs have an average diameter of $21 \mathrm{~nm}$.It is possible that AgNPs are stabilized by binding to proteins of pomegranate extract. RGO shows typical sheet-like structures as shown in Fig. (2b). The adhered AgNPs have spherical morphologies as shown in Fig. $(2 c-e)$.
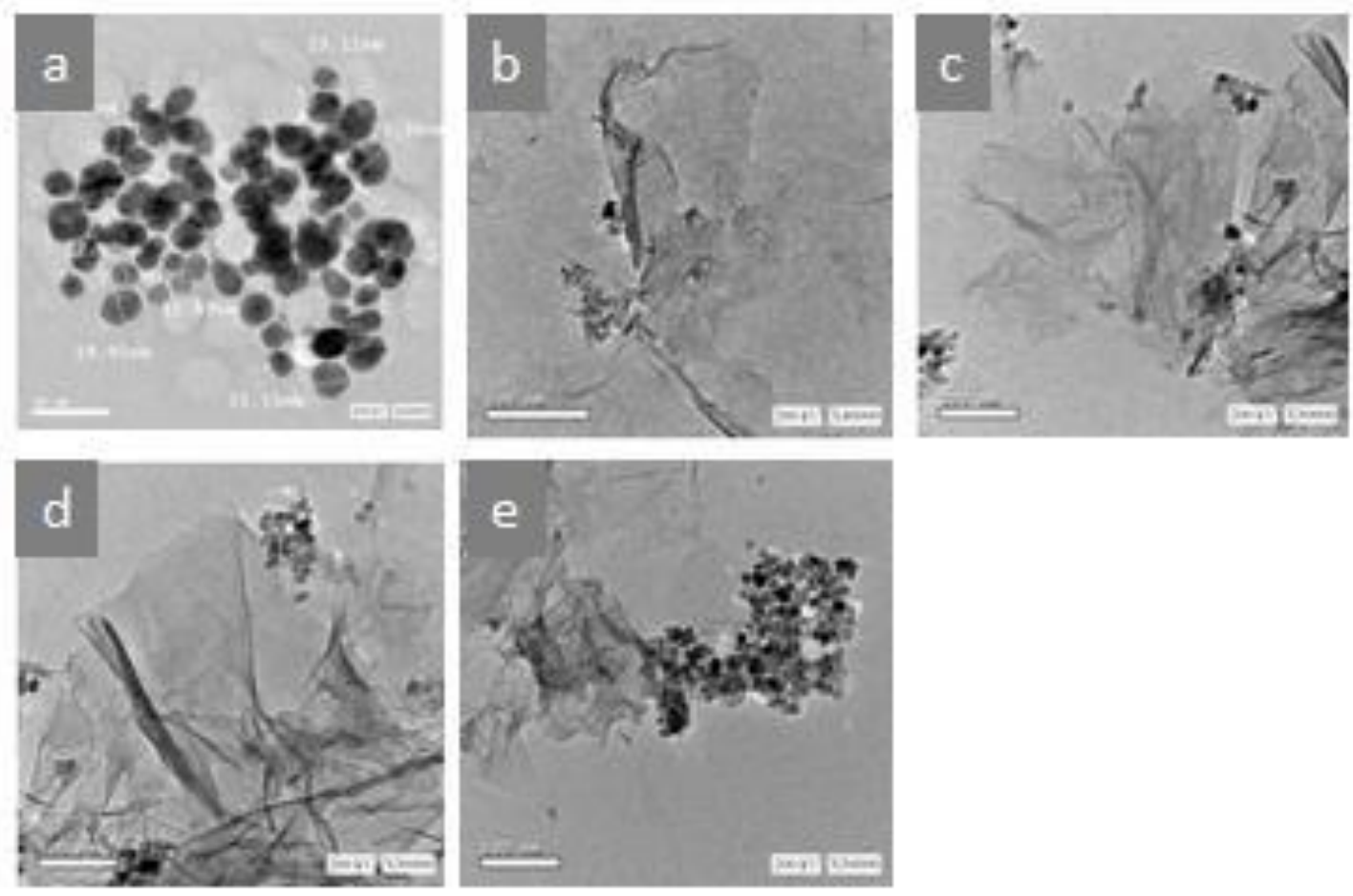

Figure 2: HR-TEM images of (a) AgNPs, (b) RGO (c)10\%wt Ag-RGO, (d) $20 \%$ wt AgRGO and (e) $30 \%$ wt Ag-RGO

The Raman spectra of GO, RGO and20 wt\% Ag-RGO nanocomposite were shown in Fig (3). GO showed intense D band at $1349 \mathrm{~cm}^{-1}$ and normal G-band at $1588 \mathrm{~cm}^{-1}$. The G band is corresponding to $\mathrm{sp}^{2}$ hybridized carbon atoms while the D-band is attributed to the high level of oxidation, which resulted in defects on GO nanosheets surface and lattice distortion (Sedki et al., 2015). Another peak at $2905 \mathrm{~cm}^{-1}$ denoted by 2D-band is attributed to the development of graphene structure. The intensity ratio of the $\mathrm{D}$ to $\mathrm{G}$ bands (ID/IG) increases to 1.42 (Ag-RGO nanocomposite) from 1.13 (RGO) and 0.94 (GO) indicating that the size of the $\mathrm{sp}^{2}$ domain decreases as the graphene sheet is broken into fragments during the AgNPs treatment (Zhang et al., 2011). 


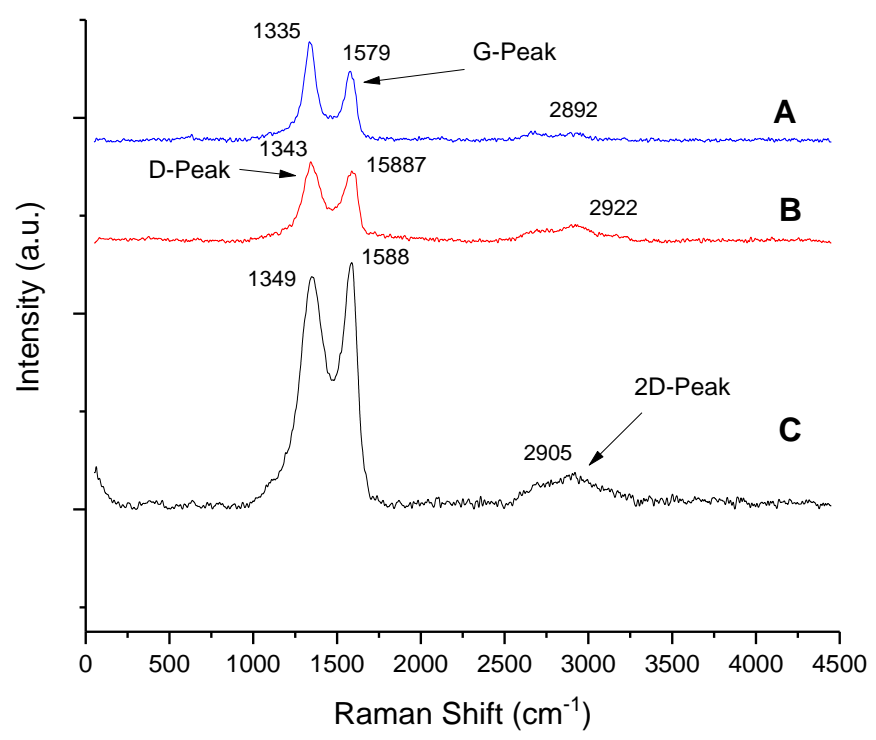

Figure 3: Raman spectra of graphene oxide (GO), reduced graphene oxide (RGO) and 20 wt\% Ag-RGO nanocomposites.

\subsection{Sorption Studies}

\subsubsection{The effect of different Ag NPs loading on RGO efficiency}

The effect of Ag NPs loading on the RGO uptake efficiency was investigated. Fig. 4 shows the results of $\mathrm{Pb}^{2+}$ and $\mathrm{Zn}^{2+}$ metal ions removal using Ag-RGO nanocomposites, with different Ag loading ratios in comparison with RGO. The optimum Ag loading ratio for effective removal $\mathrm{Pb}^{2+}$ and $\mathrm{Zn}^{2+}$ metal ions was $20 \mathrm{wt} \% \mathrm{Ag}-\mathrm{RGO}$ and $30 \mathrm{wt} \% \mathrm{Ag}-$ RGO respectively. The optimal removal efficiency was reached $100 \%$ for $\mathrm{Pb}^{2+}$ metal ions while reached $71 \%$ for $\mathrm{Zn}^{2+}$ metal ions within four hours using $50 \mathrm{mg} \mathrm{L}^{-1}$ metal ions initial concentration. The RGO loaded with $20 \% \mathrm{Ag}$ NPs provided the highest efficiency due to more adsorption sites whereas higher loading dramatically decreased the adsorption efficiency for $\mathrm{Zn}^{2+}$ metal ions. A possible reason for this is related to the high density of Ag NPs on the RGO surface in which a continuous Ag film was formed. Until now, it is unclear why the efficiency dramatically decreased, and more work is needed to obtain a clear understanding, nevertheless, a proper loading of Ag NPs with about $20 \%$ can provide maximum removal efficiency for $\mathrm{Zn}^{2+}$ metal ions. Subsequently, for $\mathrm{Pb}^{2+}$ metal ions removal, it is expected that removal efficiency will decrease by increasing $\mathrm{Ag}$ NPs loading more than $30 \%$ loading ratio.

The $\mathrm{pH}$ is an important factor affecting the removal of metal ions from aqueous solutions. Dependence of metal sorptionon $\mathrm{pH}$ is related to both the metal chemistry in the solutionand the ionization state of functional groups of the adsorbentwhich affects the availability of binding sites (Heidari et al., 2009; Ngomsik et al., 2009). The pH ranges 
werechosen 6 in order to avoid precipitation of metal ions in the form of metalhydroxides at $\mathrm{pH}>6$ (El-Sayed et al., 2016).

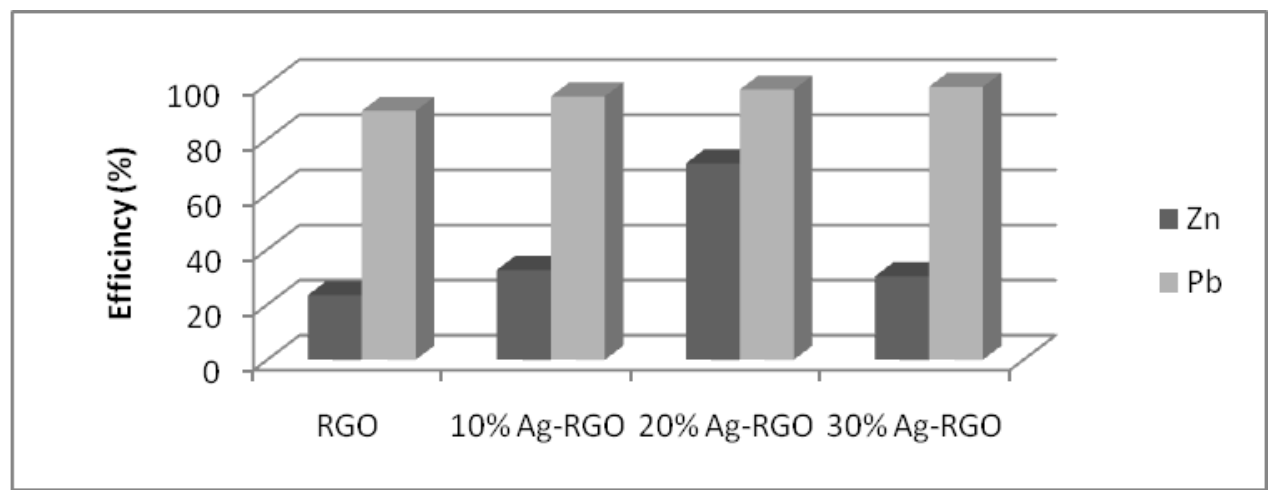

Figure 4: Efficiency of RGO and different Ag-RGO nanocomposites for $\mathrm{Zn}(\mathrm{II})$ and $\mathrm{Pb}$ (II) metals removal.

\subsubsection{Effect of Contact Time and Adsorption kinetics:}

The adsorption behavior of $\mathrm{Zn}$ (II) and $\mathrm{Pb}$ (II) on $\mathrm{Ag}$-RGO nanocomposite at initial concentration of $50 \mathrm{ppm}$, pH 6.0 and adsorbent dosage of $2.5 \mathrm{~g} / \mathrm{l}$ of $20 \% \mathrm{Ag}-\mathrm{RGO}, 30 \%$ $\mathrm{Ag}-\mathrm{RGO}$ for removal of $\mathrm{Zn}$ (II) and $\mathrm{Pb}$ (II), respectively as a function of contacting time was shown in Fig. 5. It could be seen that the percentage metal ions removal approached equilibrium within $3 \mathrm{hrs}$ for $\mathrm{Zn}$ (II) and $\mathrm{Pb}$ (II) recording $78 \% \mathrm{Zn}$ (II) removal and 99.4\% $\mathrm{Pb}$ (II) removal.It is clear that the removal percentage of $\mathrm{Pb}$ (II) is greater than $\mathrm{Zn}$ (II). This can be attributed to the value of hydrated radius of $\mathrm{Zn}^{2+}\left(4.30 \mathrm{~A}^{\circ}\right)$ which is greater than that of $\mathrm{pb}^{2+}\left(4.01 \mathrm{~A}^{\circ}\right)$ (Calvo et al., 2009) Therefore, it is possible that the smaller hydrated $\mathrm{pb}^{2+}$ ions reaches sited inaccessible to $\mathrm{Zn}^{2+}$ ions. Moreover, $\mathrm{Pb}$ (II) has higher electronegativity than those of $\mathrm{Zn}$ (II) in which the metal with greater electronegativity exhibits greater adsorption.

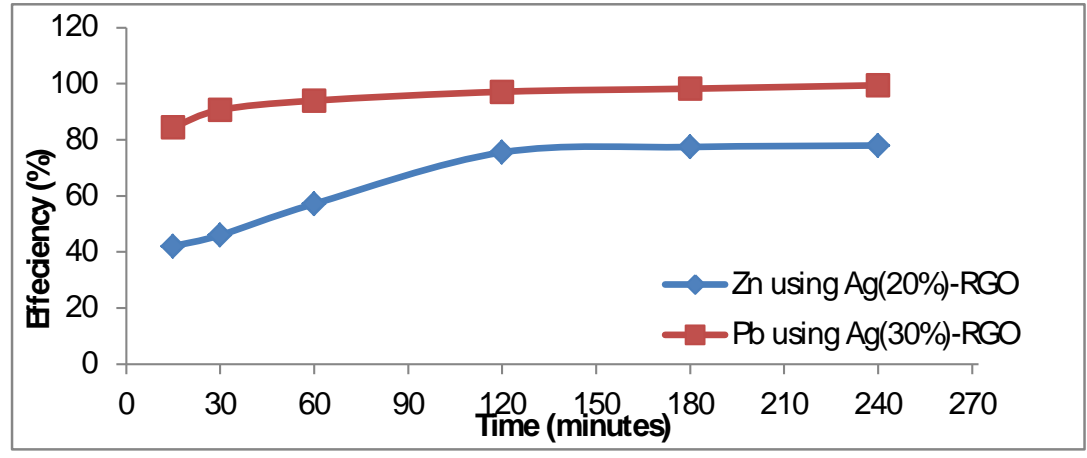

Figure 5: Effect of contact time on the adsorption ofZn (II) and $\mathrm{Pb}$ (II) by Ag-RGO nanocomposites 
For further analysis of the results, several kinetic models are investigated to describe the adsorption kinetics. In this study, the pseudo-first-order and pseudo-second order model equations were used to investigate the kinetics of metal adsorption on the Ag-RGO composite (Fang et al., 2018). The linear form of the pseudo-first order kinetic model for the adsorption of solid/liquid systems could be expressed as: $\operatorname{Ln}\left(q_{e}-q_{t}\right)=\frac{\operatorname{Ln}\left(q_{e}\right)-k_{1 p} t}{2.303}$. Straight-line plots of $\operatorname{Ln}(q \mathrm{e}-q \mathrm{t})$ against $t$ were used to determine the rate constant, $\mathrm{k}_{1}$.Ho and McKay's pseudo-second order kinetic model can be expressed as: $\frac{t}{q_{t}}=\frac{1}{2 k q_{e}^{2}}+\frac{t}{q_{\mathrm{e}}}$.Straight-line plots of $t / q_{t}$ against $t$ were tested to obtain rate parameters. Where $\mathrm{q}_{\mathrm{e}}$ and $\mathrm{q}_{\mathrm{t}}$ are the amounts of metal ion adsorbed on adsorbent at equilibrium $(\mathrm{mg} / \mathrm{g})$ and time $\mathrm{t}$, respectively. $\mathrm{k}_{1}$ is the equilibrium rate constant of the pseudo-first order adsorption $\left(\mathrm{min}^{-1}\right) . \mathrm{k}_{2}$ is the equilibrium rate constant of the pseudosecond order adsorption (g/mg.min).The kinetic parameters for $\mathrm{Zn}$ (II) and $\mathrm{Pb}(\mathrm{II})$ adsorption on the Ag-RGO nanocomposite for $\mathrm{Zn}(\mathrm{II})$ and $\mathrm{Pb}(\mathrm{II})$ are illustrated in Table 1 .

Table 1: Adsorption kinetic parameters for $\mathrm{Zn}(\mathrm{II})$ and $\mathrm{Pb}$ (II) adsorption on the Ag-RGO nanocomposite

Pseudo-first-order kinetics

Pseudo-second-order kinetics

\begin{tabular}{llllllll}
\hline Metal ions & $\begin{array}{l}\mathrm{K}_{1} \\
\left(\mathrm{~min}^{-1}\right)\end{array}$ & $\begin{array}{l}q_{e, \mathrm{cal}} \\
\left(\mathrm{mg} \cdot \mathrm{g}^{-1}\right)\end{array}$ & $R^{2}$ & $\begin{array}{l}k_{2} \\
\left(\mathrm{~g} \cdot \mathrm{mg}^{-1} \cdot \mathrm{min}^{-1}\right)\end{array}$ & $\begin{array}{l}q_{e, \mathrm{cal}} \\
\left(\mathrm{mg} \cdot \mathrm{g}^{-1}\right)\end{array}$ & $\begin{array}{l}q_{e, \text { exp }} \\
\left(\mathrm{mg} \cdot \mathrm{g}^{-1}\right)\end{array}$ & $R^{2}$ \\
\hline $\mathrm{Zn}$ & $\mathbf{0 . 0 1 8 4}$ & $\mathbf{0 . 7 8}$ & $\mathbf{0 . 8 9}$ & $\mathbf{0 . 0 0 2 6}$ & 16.95 & 15.176 & 0.99 \\
\hline $\mathrm{Pb}$ & $\mathbf{0 . 0 1 9 1}$ & $\mathbf{0 . 7 9}$ & $\mathbf{0 . 8 8}$ & $\mathbf{0 . 0 2 2 7}$ & 12.19 & 11.786 & 0.99 \\
& & & & & & & \\
\hline
\end{tabular}

The results show that the correlation coefficients of determination $\left(\mathrm{R}^{2}\right)$ for pseudosecond-order model are higher compared with those of pseudo-first-order one and the calculated $\mathrm{q}_{\mathrm{e}}$ values $\left(\mathrm{q}_{\mathrm{e}}, \mathrm{cal}\right)$ from this model agree well with the experimental data $\left(\mathrm{q}_{\mathrm{e}, \exp }\right)$.These results suggest that the pseudo-second order model was more appropriate to describe the adsorption kinetics behavior for $\mathrm{Zn}$ (II) and $\mathrm{Pb}$ (II) ions onto $\mathrm{Ag}-\mathrm{RGO}$ nanocoposite. The fitting of the experimental data to the pseudo-second order model, as shown in Fig.6, indicates that the adsorption of $\mathrm{Zn}$ (II) and $\mathrm{Pb}$ (II) on Ag-RGO nanocomposite is controlled by chemical adsorption (chemisorption) involving valence forces through sharing or exchange electrons between sorbent and sorbate. In the chemical adsorption, it is assumed that, the adsorption capacity is proportional to the number of active sites occupied on the adsorbent surface (Kula et al., 2008). 


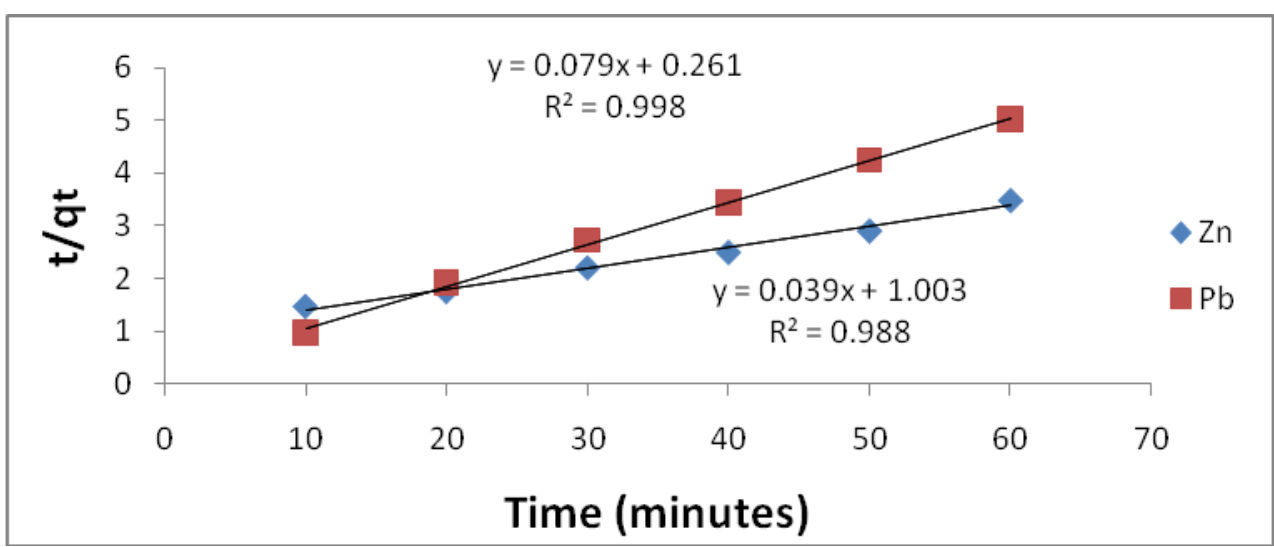

Figure 6: Pseudo $2^{\text {nd }}$ order kinetic model for the adsorption of $\mathrm{Zn}$ (II) and $\mathrm{Pb}$ (II) on $\mathrm{Ag}$ RGO nanocomposite.

\subsection{Effect of Adsorbent dose:}

The optimum amount of the adsorbent required for quantitative removal of $50 \mathrm{ppm}$ of $\mathrm{Zn}$ (II) and $\mathrm{Pb}$ (II) metal ions was determined by operating various dosages; 0.03, 0.05, 0.07 and $0.1 \mathrm{~g}$ which represent adsorbent concentrations of $1.5,2.5,3.5$ and $5 \mathrm{~g} / \mathrm{L} \mathrm{of} \mathrm{Ag}-$ RGO at contact time $3 \mathrm{hrs}, \mathrm{pH} 6.0$. Fig. 7 shows that as the dosage increase, the percentage of metal ions removal increase. This can be attributed to the increased availability of adsorption sites. It is noticed that at adsorbent conc. equal to $5 \mathrm{~g} / \mathrm{L}$ the uptake efficiency reaches about $97.5 \%$ and $100 \%$ for $\mathrm{Zn}$ (II) and $\mathrm{Pb}$ (II) ions removal.

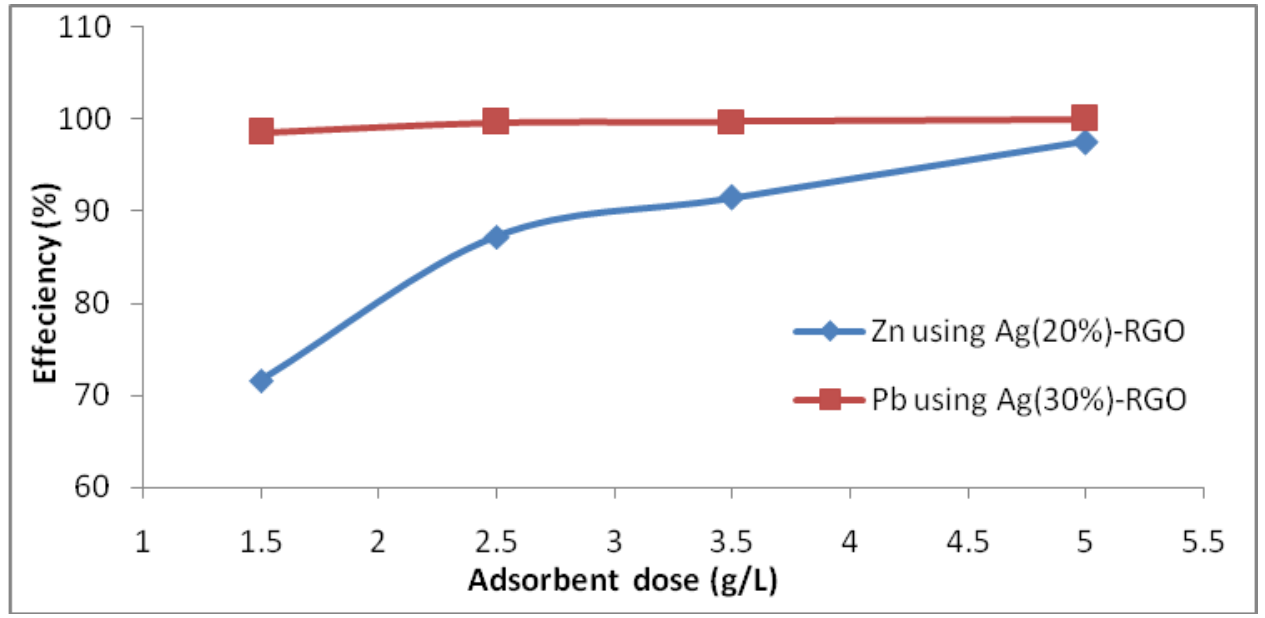

Figure 7: Effect of adsorbent concentration on adsorption efficiency for $\mathrm{Zn}$ (II) and $\mathrm{pb}$ (II) from aqueous solution using Ag-RGO nanocomposite.

\subsubsection{Effect of initial metal ion concentration and the adsorption isotherms}

The effect of initial concentrations of $\mathrm{Zn}(\mathrm{II})$ and $\mathrm{Pb}(\mathrm{II})$ ions was examined using different concentrations varying from 5 to $200 \mathrm{ppm}$ using $2 \mathrm{~g} / \mathrm{L}$ adsorbent dosage as shown in Fig.8. It can be seen that the uptake capacity of Ag-RGO composite increases 
with the increase of the initial metal ion concentration. The maximum capacity reached is $27.1 \mathrm{mg} / \mathrm{g}$ and $34.8 \mathrm{mg} / \mathrm{g}$ for removal of $\mathrm{Zn}$ and $\mathrm{Pb}$ respectively and the uptake capacity increased with the increase of concentration. The increased number of themetal ions in the solution increases the opportunity of the active group to bind with the metal ion which increases the uptake efficiency.

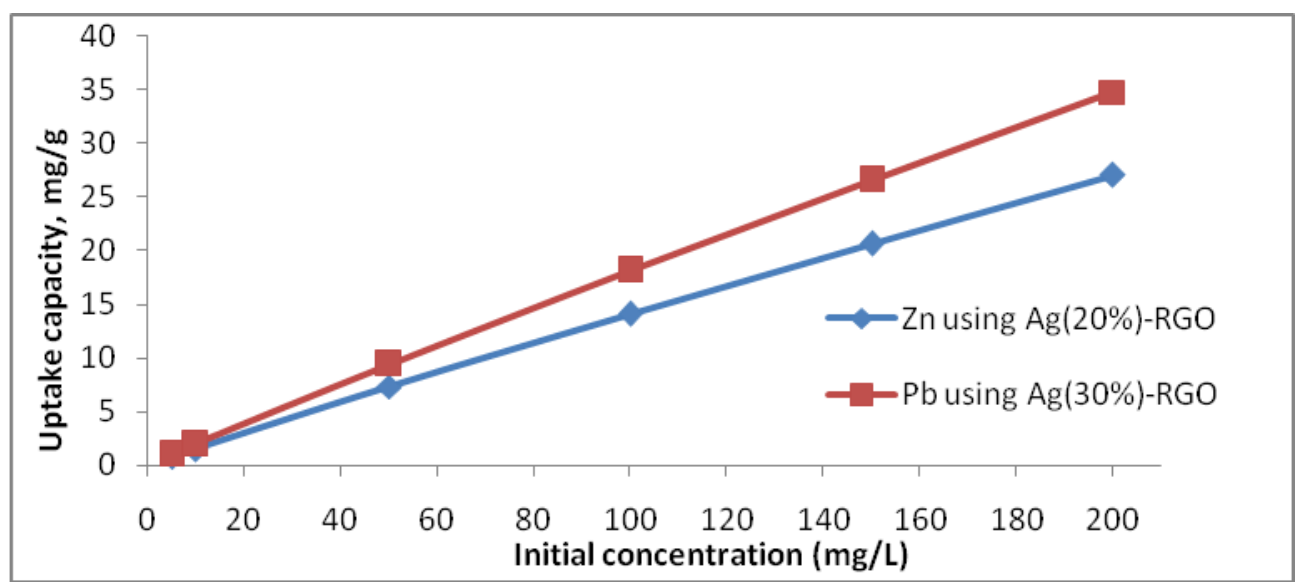

Figure 8: Effect of $\mathrm{Zn}(\mathrm{II})$ and $\mathrm{Pb}(\mathrm{II})$ ions concentration the uptake capacity of $\mathrm{Ag}-\mathrm{RGO}$ nanocomposite.

Langmuir as well as Freundlich models (Fang $\boldsymbol{e t}$ al., 2018) are widely being used to describe solid-liquid adsorption systems, both are tested for $\mathrm{Zn}$ (II) and $\mathrm{Pb}$ (II) adsorption process. Langmuir isotherm is often applicable to the homogeneous surfaces, in which all the adsorption sites have equal affinity towards the adsorbate, only monolayer adsorption occurs in the process. In contrast, Freundlich model advocate heterogeneity of surface having different adsorption energy for different sites leading to the multilayer adsorption. The linear form of Langmuir isotherms can be described as follows $\mathrm{C}_{\mathrm{e}} / \mathrm{q}_{\mathrm{e}}$ $=1 /\left(\mathrm{q}_{\max } \mathrm{b}\right)+\mathrm{C}_{\mathrm{e}} / \mathrm{q}_{\max }$ Where $\mathrm{C}_{\mathrm{e}}(\mathrm{mg} / \mathrm{L})$ is the equilibrium concentration of $\mathrm{Zn}(\mathrm{II})$ and $\mathrm{Pb}(\mathrm{II})$ , $\mathrm{q}_{\mathrm{e}}(\mathrm{mg} / \mathrm{L})$ is the amount of ions adsorbed at equilibrium, $\mathrm{q}_{\max }$ is the maximum monolayer adsorption capacity and $b$ is the Langmuir adsorption constant $(\mathrm{L} / \mathrm{mg})$. Freundlich equation was expressed as followsLog $\left(\mathrm{q}_{\mathrm{e}}\right)=\log \left(\mathrm{K}_{\mathrm{F}}\right)+1 / \mathrm{n} \log \left(\mathrm{C}_{\mathrm{e}}\right) \quad$ Where $\mathrm{K}_{\mathrm{F}}$ is the Freundlich isotherm constant, and $\mathrm{n}$ (dimensionless) is the heterogeneity factor. As shown in Fig.9, the correlation coefficients $\left(\mathrm{R}^{2}\right)$ of the linear form of Freundlich model were much closer to 1.0 than this of linear Langmuir form Fig.10.Freundlich model provides the most satisfactory description for the $\mathrm{Zn}$ (II) and $\mathrm{Pb}$ (II) adsorption. These finding are well matched with the geometrical structure of the multilayered AgRGO where this adsorbent contains different binding sites in addition to the inter- and intra-layers sites.Different adsorption parameters calculated using these two models are shown in Table 2. From the correlation coefficients, it is clearly evident that $\mathrm{Zn}$ (II) and 
$\mathrm{Pb}$ (II) adsorption process by Ag-RGO composite are better described by Freundlich model than the Langmuir model.

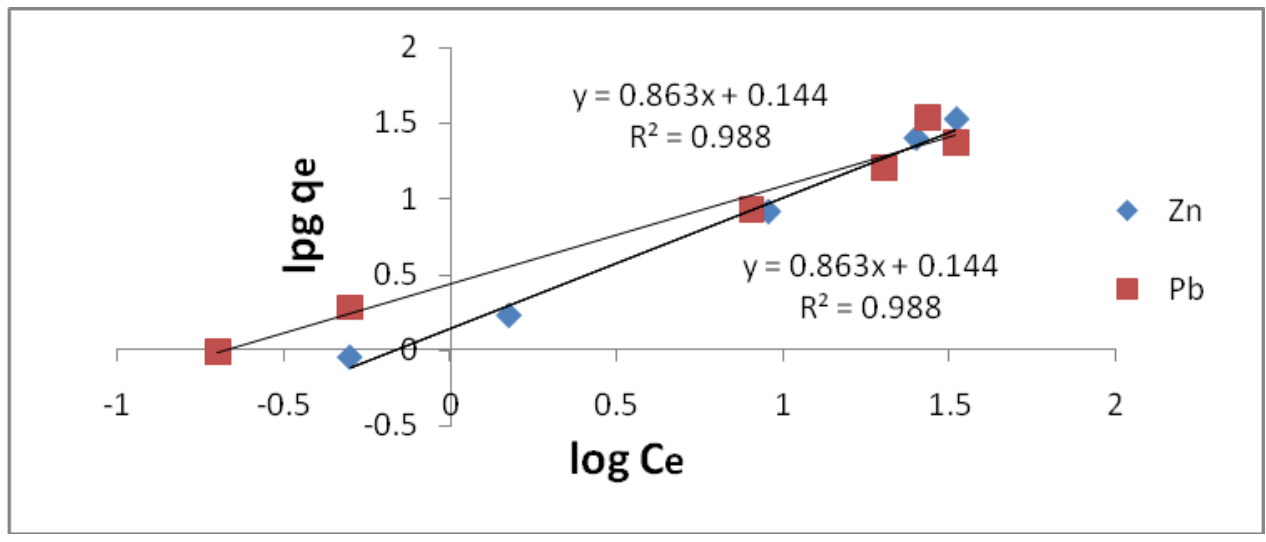

Figure 9: Freundlich adsorption isotherm for $\mathrm{Zn}(\mathrm{II})$ and $\mathrm{Pb}(\mathrm{II})$ adsorption ontoAg- $\mathrm{RGO}$ nanocomposite.

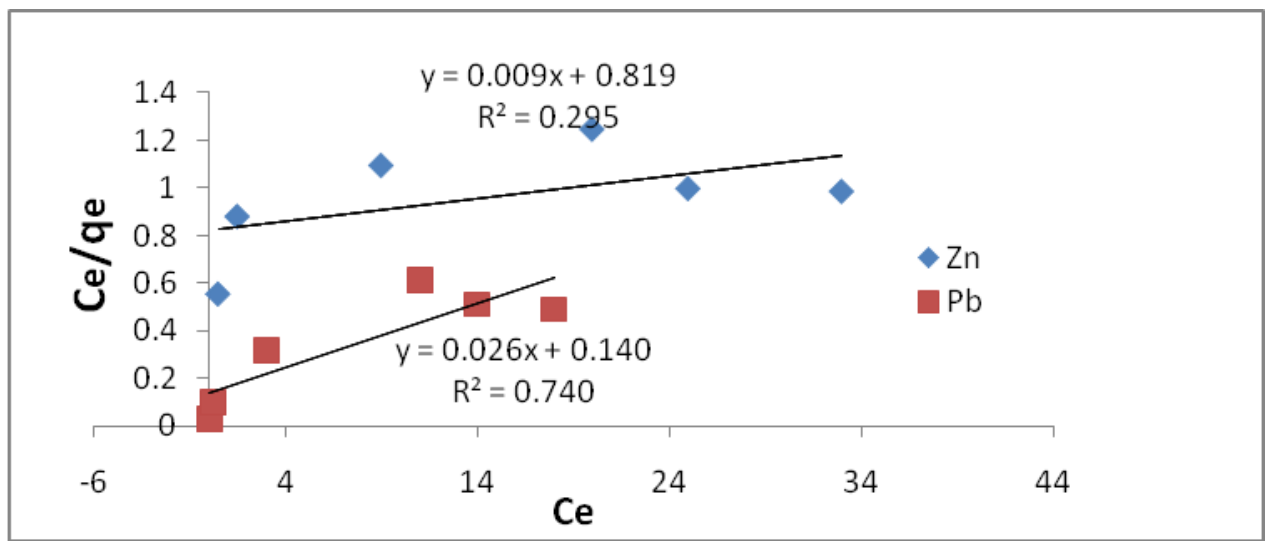

Figure 10: Langmuir adsorption isotherm for $\mathrm{Zn}(\mathrm{II})$ and $\mathrm{Pb}(\mathrm{II})$ adsorption onto Ag-RGO nanocomposite.

\section{CONCLUSION}

In summary, Ag-RGO nano-composite was successfully prepared by one-pot phytoreduction of Ag-GO suspension using pomegranate peel extract (PPE) as capping and reducing agent. Compared to virgin RGO, Ag-RGO nano-composite exhibited higher adsorption efficiency in removing $\mathrm{Zn}$ (II) and $\mathrm{Pb}$ (II) from aqueous solution. The adsorption followed pseudo second-order kinetics and the equilibrium data were well fitted with the Freundlich isotherms. The Ag-RGO nanoadsorbent exhibits a bright future for practical applications in heavy metal removal from the wastewater. 


\section{ACKNOWLEDGEMENT}

H. El-Sabban would like to thank Dr. A. Hamdy, Dr. Amr A. Nada, Dr. Hager R. Ali andEgyptian Petroleum Research Institute for offering graphene samples and help in preparation of Ag-NPs.

This work is a part of the Ph.D. thesis of H. El-Sabban and the authors have nothing to declare regarding conflicts of interest

\section{REFERENCES}

Ahmad, N.; Sharma, S. and Rai, R. (2012). Rapid green synthesis of silver and gold nanoparticles using peels of Punica granatum. Advanced Materials Letters, 3 (5): 376380.

Al-Qahtani, K. M. (2017). Cadmium removal from aqueous solution by green synthesis zero valent silver nanoparticles with Benjamina leaves extract. The Egyptian Journal of Aquatic Research, 43 (4): 269-274.

Bernard, E.; Jimoh, A. and Odigure, J. (2013). Heavy metals removal from industrial wastewater by activated carbon prepared from coconut shell. Research Journal of Chemical Sciences - ISSN, 2231: 606X.

Calvo, B.; Canoira, L.; Morante, F.; Martínez-Bedia, J. M.; Vinagre, C.; GarcíaGonzález, J.-E.; Elsen, J. and Alcantara, R. (2009). Continuous elimination of $\mathrm{Pb}^{2+}$, $\mathrm{Cu}^{2+}, \mathrm{Zn}^{2+}, \mathrm{H}^{+}$and $\mathrm{NH}^{4+}$ from acidic waters by ionic exchange on natural zeolites. Journal of hazardous materials, 166 (2-3): 619-627.

Edison, T. J. I. and Sethuraman, M. (2013). Biogenic robust synthesis of silver nanoparticles using Punica granatum peel and its application as a green catalyst for the reduction of an anthropogenic pollutant 4-nitrophenol. Spectrochimica Acta Part A: Molecular and Biomolecular Spectroscopy, 104: 262-264.

El-Maghrabi, H. H.; Abdelmaged, S. M.; Nada, A. A.; Zahran, F.; El-Wahab, S. A.; Yahea, D.; Hussein, G. and Atrees, M. (2017). Magnetic graphene based nanocomposite for uranium scavenging. Journal of hazardous materials, 322: 370-379.

El-Sayed, M.; Eshaq, G. and ElMetwally, A. (2016). Adsorption of heavy metals from aqueous solutions by $\mathrm{Mg}-\mathrm{Al}-\mathrm{Zn}$ mingled oxides adsorbent. Water Science and Technology, 74 (7): 1644-1657. 
Fang, L.; Li, L.; Qu, Z.; Xu, H.; Xu, J. and Yan, N. (2018). A novel method for the sequential removal and separation of multiple heavy metals from wastewater. Journal of hazardous materials, 342: 617-624.

Heidari, A.; Younesi, H. and Mehraban, Z. (2009). Removal of Ni (II), Cd (II), and Pb (II) from a ternary aqueous solution by amino functionalized mesoporous and nano mesoporous silica. Chemical Engineering Journal, 153 (1-3): 70-79.

Kula, I.; Uğurlu, M.; Karaoğlu, H. and Celik, A. (2008). Adsorption of Cd (II) ions from aqueous solutions using activated carbon prepared from olive stone by $\mathrm{ZnCl} 2$ activation. Bioresource technology, 99 (3): 492-501.

Minhas, F. T.; Arslan, G.; Gubbuk, I. H.; Akkoz, C.; Ozturk, B. Y.; Asıkkutlu, B.; Arslan, U. and Ersoz, M. (2018). Evaluation of antibacterial properties on polysulfone composite membranes using synthesized biogenic silver nanoparticles with Ulva compressa (L.) Kütz. and Cladophora glomerata (L.) Kütz. Extracts. International journal of biological macromolecules, 107: 157-165.

Ngomsik, A.-F.; Bee, A.; Siaugue, J.-M.; Talbot, D.; Cabuil, V. and Cote, G. (2009). Co (II) removal by magnetic alginate beads containing Cyanex 272®. Journal of hazardous materials, 166 (2-3): 1043-1049.

Rengga, W. D. P.; Chafidz, A.; Sudibandriyo, M.; Nasikin, M. and Abasaeed, A. E. (2017). Silver nano-particles deposited on bamboo-based activated carbon for removal of formaldehyde. Journal of Environmental Chemical Engineering, 5 (2): 1657-1665.

Sedki, M.; Mohamed, M. B.; Fawzy, M.; Abdelrehim, D. A. and Abdel-Mottaleb, M. M. (2015). Phytosynthesis of silver-reduced graphene oxide (Ag-RGO) nanocomposite with an enhanced antibacterial effect using Potamogeton pectinatus extract. RSC Advances, 5 (22): 17358-17365.

Song, S.; Wang, H.; Song, A. and Hao, J. (2014). Superhydrogels of Nanotubes Capable of Capturing Heavy- Metal Ions. Chemistry-An Asian Journal, 9 (1): 245-252.

Suman; Kardam, A.; Gera, M. and Jain, V. (2015). A novel reusable nanocomposite for complete removal of dyes, heavy metals and microbial load from water based on nanocellulose and silver nano-embedded pebbles. Environmental Technology, 36 (6): 706-714.

Uçar, S.; Erdem, M.; Tay, T. and Karagöz, S. (2015). Removal of lead (II) and nickel (II) ions from aqueous solution using activated carbon prepared from rapeseed oil cake by $\mathrm{Na}_{2} \mathrm{CO}_{3}$ activation. Clean Technologies and Environmental Policy, 17 (3): 747-756. 
Uçar, S.; Erdem, M.; Tay, T. and Karagöz, S. (2015). Removal of lead (II) and nickel (II) ions from aqueous solution using activated carbon prepared from rapeseed oil cake by $\mathrm{Na}_{2} \mathrm{CO}_{3}$ activation. Clean Technologies and Environmental Policy, 17 (3): 747-756.

Wang, X.; Guo, Y.; Yang, L.; Han, M.; Zhao, J. and Cheng, X. (2012). Nanomaterials as sorbents to remove heavy metal ions in wastewater treatment. J. Environ. Anal. Toxicol, 2 (7): 154.

Zhang, Z.; Xu, F.; Yang, W.; Guo, M.; Wang, X.; Zhang, B. and Tang, J. (2011). A facile one-pot method to high-quality Ag-graphene composite nanosheets for efficient surface-enhanced Raman scattering. Chemical Communications, 47 (22): 6440-6442. 